\title{
湿潤環境下にわける毛管力作用下での銅の腐食*
}

\author{
松岡宏昌**, 松永義弘**, 光本誠一**, 関肇*** \\ ** 三菱電機 (株) 材料研究所 \\ $* * *$ 三菱電機 (株) 神戸製作所
}

\section{Copper Corrosion Affected by Capillary Action in Humid Atmosphere*}

\author{
Hiromasa Matsuoka** Yoshihiro Matsunaga** Seiichi Mitsumoto** \\ and Hajime Seki*** \\ ** Materials and Electronic Devices Laboratory, Mitsubishi Electric Co. \\ *** Kobe Works, Mitsubishi Electric Co.
}

\begin{abstract}
Some physical as well as chemical factors would take part in the appearance of corrosion morphology of metals in humid environment. In this paper, some cases of corrosion on the copper alloy were demonstrated which were caused by the capillary action due to superficial structure of the metal. A model was proposed in which the capillary force can be calculated as a function of the equivalent capillary radius which results from the superficial structure of the metal. Pitting experiments were performed by placing different size of glass beads with various electrolytes on copper plates. The correlation between the depth and diameter of the generated pits and the size of glass beads was examined. It was confirmed that the diameter of the pits was strongly affected by the diameter of the glass beads. The diameter of pits caused by small glass beads was smaller than that caused by large galss beads. It was suggested that the corrosion morphology in humid atmosphere was affected by the capillary action in the present experiment.
\end{abstract}

Keywords: corrosion morphology, copper, humid environment, capillary action, superficial structure, pitting experiments

\section{1. 緒言}

腐食現象には一般に複数の物理・化学現象が関係して いる。湿潤状態で金属表面に存在する電解液は一般に表 面張力により負圧状態にあり，金属表面が細隙部を有す る形状である場合，毛管力の作用が腐食現象に影響して いると思われる。

例壳ば，冷凍機用銅パイプの製造工程中で生じた嶬の 巣状腐食 ${ }^{11}$, 雨水などの浸入する条件で硬銅線の撚線に 生じた応力腐食2) の添か, 塗膜下金属表面任生じる系状

* (社) 腐食防食協会第 32 回腐食防食討論会で発表 (札幌)

** T661 尼崎市塚口本町 8-1-1 (1-1, Tsukaguchi Honmachi, 8-chome, Amagasaki, Hyogo, 661 Japan)

*** 干652 神戸市兵庫区和田崎町 1-1-2 (1-2, Wadasakicho 1 chome, Hyogoku, Kobe, 652 Japan)
腐食なども毛管力の影響を受けた腐食の例と思われる。 本報は筆者らが体験した毛管力によると考兄られるり 几銅ろらによるろら付部の腐食3)，銅パイプにろう付し た後に生じた蟻の巣状腐食の二つの事例紹介と, 毛管力 の影響を確認するために行った実験の結果を述べる。

\section{2. 毛管力の影響を受けていると思われる腐食の例}

\section{1 りん銅ろうによるろう付部の腐食}

Fig. 1 は希薄 $\mathrm{H}_{2} \mathrm{~S}$ 含有空気中でりん銅ろう (BCuP5）による銅の突き合わせろう付部に生じた腐食の断面 写真である。ろら材と母材 (銅) の境界が選択的に幅せま く侵食されて扣り，その部分に腐食生成物があをり見あ たらない。

この腐食は, ろら材の腐食によってろら材中のりんが 酸化され空気中の水分を吸収してり几酸（腐食生成物よ り熱湯抽出 JIS K 0102.46.1.2 吸光光度法によって確認 


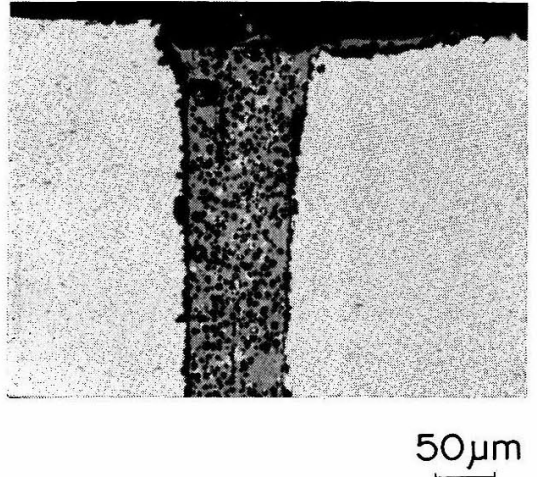

Fig. 1 Corrosion of a copper joint brazed by B Cup-5 as the braze metal (Cross sectional micrograph).

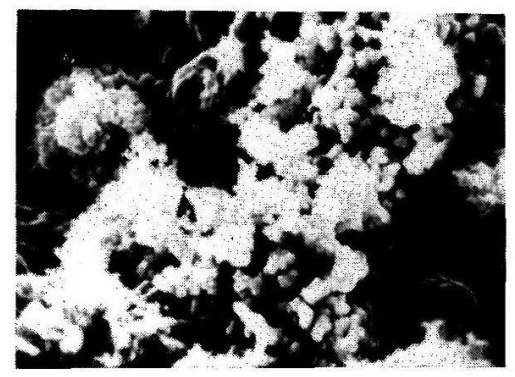

\section{$4 \mu \mathrm{m}$}

Fig. 2 Corrosion products on a copper joint brazed by B Cup- 5 as the braze metal (SEM micrograph).

した）を生じこれがらら材から母材表面にわたって広 がり，母材表面をカソードとする電池を形成することに より加速度的に進行したとみられる。すなわる，Fig. 2 に見るように，母材表面には粒状の㢁食生成物（主とし て $\mathrm{Cu}_{2} \mathrm{~S}, \mathrm{XD}$ 及び IR により同定, その他微量の CuS が含まれている。)が堆積してあり，りん酸はこの粒子間 及び粒子と母材表面とのすき間に存在し，すき間の等価 毛管半径によって決李る毛管力（負圧）を生じていると 考光られる。したがって, 万ら材と接する母材が一定以 上に腐食されすき間が大きくなると，このすき間の毛管 力，ななわら，りん酸をすき間にとどめる吸引力が低下 し，すき間にあったりん酸は他に吸い取られてしまら。 したがって，をこにはりん酸は存在しないのでもはやそ 孔以上痛食しないので, 結局, ろう材と母材境界が幅狭 く腐食されたと考えられる。

母材表面の腐食生成物の粒径はりん銅るらの共晶成分 (主に $\mathrm{Cu}_{3} \mathrm{P}$ と $\mathrm{Cu}$, Fig. 3 参照) 中の $\mathrm{Cu}$ が溶出して生じ た層状のすき間の等価半径で決まる毛管力によって決定 されていると思われる。つまり，粒が成長し，粒間のす

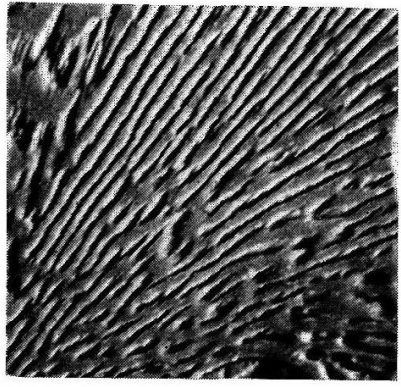

\section{$10 \mu \mathrm{m}$}

Fig. 3 Eutectic structure of the brazed copper joint (SEM micrograph).

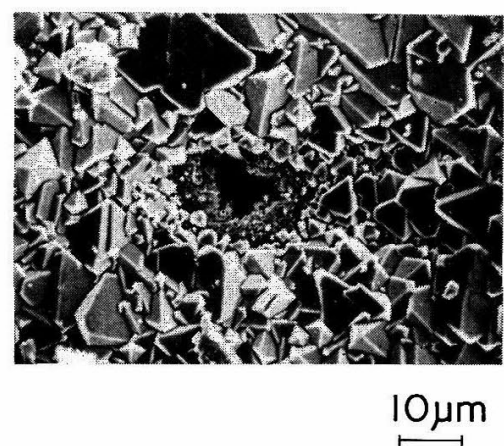

Fig. 4 SEM micrograph of the corrosion products brought about by the flux fume contamination (copper tube, test periods: 30 days).

き間の等価半径が，共晶中の $\mathrm{Cu}$ が溶出して生じたすき 間の等価半径以上になると粒間にりん酸は存在し得ず, 銅イオンの供給が断たれるので粒の成長 $\left(\mathrm{Cu}_{2} \mathrm{~S}\right.$ の成長) は停止する。

\section{2 蜂の巣状腐食}

筆者らは, 万弓付後, 水洗して放置 (雨期を経過) した 銅パイプについて，蟻の巣状腐食を体験した。この場合 のろら付にはフラックス (汪うふっ化物系) を使用して いたので，フラックスを加熱して，そのフュームを半開 した銅パイプの内面に付着させた試料を作製し, 純水を 張ったセパラブルフラスュ中の水面上の気相中に放置し た。Fig. 4 及び Fig. 5 はその結果再現された蟻の巣状腐 食である。表面に結晶状の腐食生成物 $\left(\mathrm{Cu}_{2} \mathrm{O}\right)$ が析出し て特り (Fig. 4), この面に少量の水が存在すると谷間の 一部に存在する水が，メ二スカスを生じ毛管ノを発生す る。Fig. 5 から腐食孔の中には銅に接して腐食生成物が 存在するが, 中央部分快空洞になっていることがわか る。この空洞の内径と表面の結晶状腐食生成物の寸法が あまり違って拉らず,この腐食も毛管力の影響下で生じ たと考兄れる。すなわら，後述するよらに表面の析出 


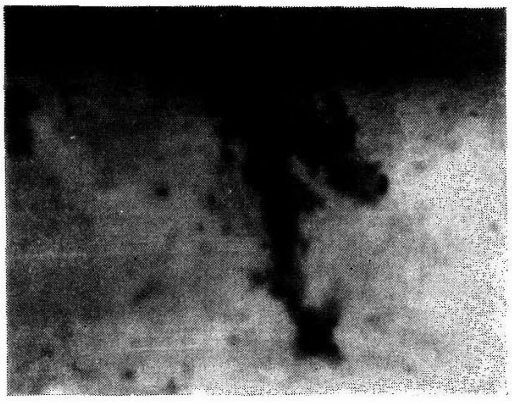

$\underset{10 \mu \mathrm{m}}{\longmapsto}$

Fig. 5 Cross-sectional micrograph of formicary corrosion in a copper tube contaminated by the flux fume (test periods: 30 days).

物形状と水の量で決まる毛管力によって定まる腐食孔を 牛ずるが孔径の拡大した孔では液が引き抜かれ腐食の進 展が停止し，一定孔径以上の孔が発展しなかったとみら れる。

\section{3. 表面状態と毛管力}

固体表面に存在する液体は，との液体によって固体表 面が犼る場合は，負圧状態にあるが，そ心圧力は表面 のミクロ形状とそこに存在する液の量によって決まる。

Fig. 6 は種々のミクロ形状に対して, 液量 $\left(h\right.$ または $\left.r_{\mathrm{m}}\right)$ 々等価毛管半径 $\left(r_{\mathrm{e}}\right)$ の関係を求めたものである。

等価毛管半径 $\left(r_{\mathrm{e}}\right)$ は気/液界面積 $(S)$ の 2 倍を気/液/固 の三相界線の長さ $(l)$ で割ったものであるから, 計算は, 液量 $\left(h\right.$ または $\left.r_{\mathrm{m}}\right)$ を変数として, 各ミクロ形状に対す る $S$ とを求め, $r_{\mathrm{e}}=2 S / l$ を計算した。Fig. 6 中の (a) (f) の 6 種のミクロ形状についての計算結果は下記の通 りであり，Fig. 6 の各直線または曲線はそれれらをグラフ 化したものである。

(a)：固体表面上の半径 $r$ 円筒状空隙 (ピンホール) に液体が存在子る場合。

$r_{\mathrm{e}}=r$

(b)：固体表面と表面上皮膜とのすき間 $(r)$ に液体が 存在する場合。

$r_{e}=r$

(c)：固体表面上に三角錐 (高さ $H$ ) が林立し, その くぼみ液体 (深さ $h$ ) が存在する場合。 $r_{\mathrm{e}}=3^{-0.5} \cdot r \cdot\left\{1-(1-h / H)^{2}\right\} /(1-h / H)$

(d)：固体表面上に半径 $r$ の小球が最密状態で堆積 (高さ $H$ ) して，小球間のすき間に $h$ まで液体 が存在する場合。

$r_{\mathrm{e}} \fallingdotseq 0.234 r$

(e)：固体表面上に球（直径 $H \equiv 2 r$ ) が一層夰んで球 の間隙に $h$ まで液体が存在する場合。

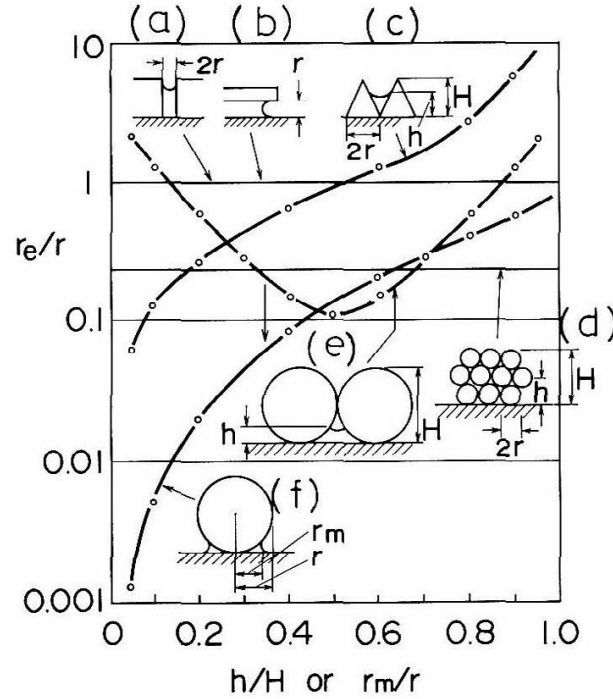

Fig. 6 Relationship between the surface structures and the resultant equivalent capillary radius.

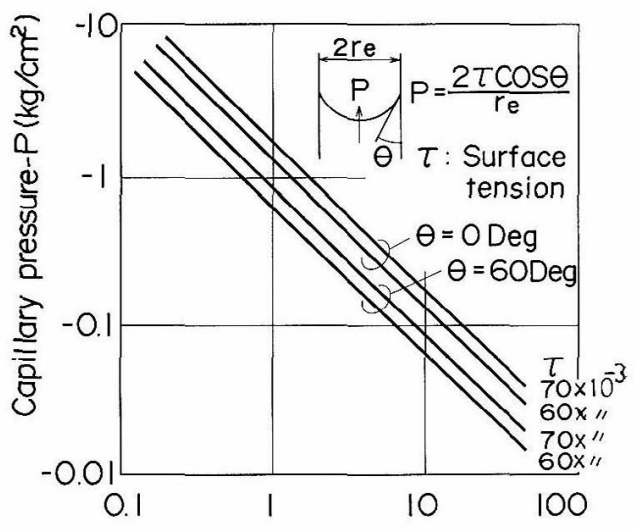

Equivalent capillary radius re $(\mu \mathrm{m})$

Fig. 7 Relationship between equivalent capillary radius and the capillary force $(\theta$ : contact angles $\left({ }^{\circ}\right), \tau$ : surface tension $(\mathrm{N} / \mathrm{m})$ ).

$$
\begin{aligned}
& r_{\mathrm{e}}=r \cdot\left\{3^{0.5} / \pi-2(h / H) \cdot(1-h / H)\right\} /\{(h / H) \cdot(1-h / \\
& H)\}^{0.5}
\end{aligned}
$$

(f)：固体表面と表面上の半径 $r$ の球との間に液体 $\left(r_{\mathrm{m}}\right)$ が存在する場合。

$r_{\mathrm{e}}=r-r \cdot\left\{1-\left(r_{\mathrm{m}} / r\right)^{2}\right\}^{0.5}$

次にその等価毛管半径の毛細管によって生ずる毛管力 (-P) と等価毛管半径の関係を接触角 $(\theta)$ が $0^{\circ}, 60^{\circ}$, 及び 表面張力 $(\tau)$ が $60 \times 10^{-3}, 70 \times 10^{-3} \mathrm{~N} / \mathrm{m}$ の場合について Fig. 7 に示した。

Fig. 6 及び Fig. 7 から固体表面に存在する液体の負 圧を知ることができる。なおメニスカス両側の各面は 
平行に対向するとして計算したので，厳密には毛管力を 求めるに当たり，接触角に両面が詨向している角度を折 り达它必要がある。

\section{4. 模 擬 実 験}

\section{1 実験方法・条件}

Fig. 8 に実験に用いたモデルを模式図で示した。困に 示したよらと、リード線を半田付けしたテストピース (銅板 C $1100,1.0$ t) と内径 $8 \mathrm{~mm}$ の銅パイプとをガラス パイプを介して接続し，銅パイプとガラスパイプの外側 をエポキシ樹脂でモールドした。パイプ内に $0.45 \mathrm{~m} l$ の 電解液と $2.5 \mathrm{~g}$ のガラスビーズ $\left(\mathrm{SiO}_{2}\right)$ を入れ, 電解液の 量はガラスビーズの空淂に対し約 $80 \%$ とした。次にシ リコンゴム栓でふたをして， $60^{\circ} \mathrm{C}$ に保持した恒温槽に 入れ， $1.5 \mathrm{~V}$ の乾電池にりード線を接続して通電した。

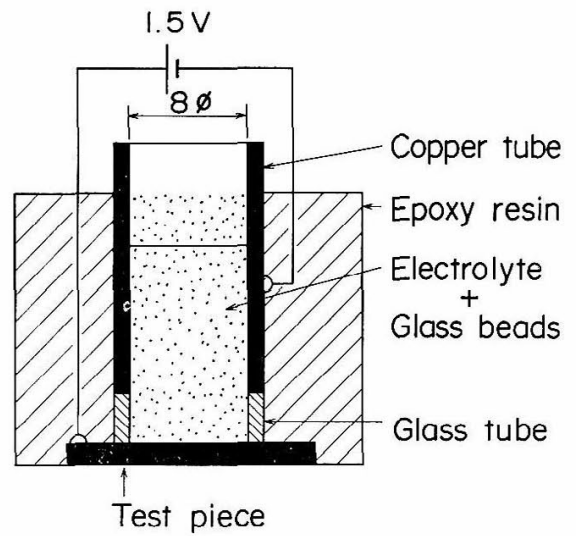

Fig. 8 A cell for the corrosion test under the capillary action by glass beads.

ガラスビーズの粒径は $50 \mu \mathrm{m}$ そ $100 \mu \mathrm{m}$ の 2 種類と 乙, 電解液は $100 \mathrm{mg} / l \mathrm{NH}_{4} \mathrm{Cl}, \mathrm{NaCl}, \mathrm{LiCl}, \mathrm{LiBr}$ 水溶液 とさらにそれぞれの電解液に $0.8 \mathrm{mg} / l$ のフィチン酸を 添加した水溶液を用いだ。通電は 11 日閒行ったが，電 流は初期に数十 $\mu \mathrm{A}$ の值を示し，時間が経過するにつれ 低下し 11 日後には数 $\mu \mathrm{A}$ の值となった。この経時変化 は電解液中の水が腐食生成物（水酸化物, 水和物, 塩基 性塩など）の生成に消費されることと蒸発により電解液 が減少するためと思われる。

\section{2 実験結果}

\subsection{1 表面写真}

通電後のテストピースは顕微鏡で観察できる程度の孔 がみられた。Fig. 9 に命の例を示した。Fig. 9 (b)では表 面以見光る大きな孔の中にるら一つの孔 (Fig. 9(c)) が 観察された。Fig. 9 (a) では孔の表面の徫と孔の底の径 とが同じであるように観察された。孔の径は後述するよ うに各ビーズについてビーズ粒径に対応して差が見られ

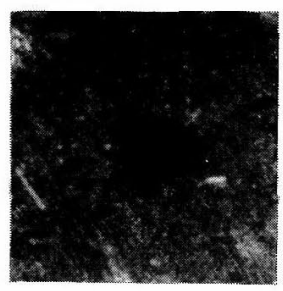

(a)

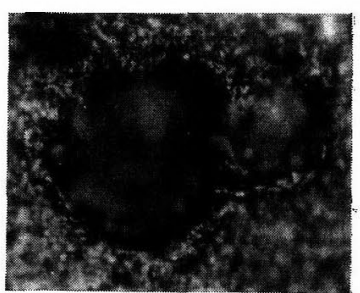

(b)

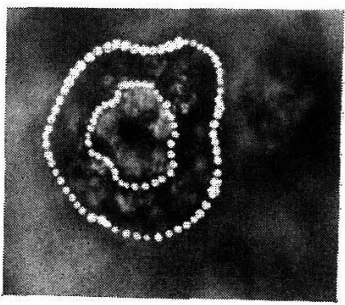

(c)
Fig. 9 Typical micrographs of corrosion pits formed under the glass beads (electrolyte: $100 \mathrm{mg} / \mathrm{L} \mathrm{LiCl}, 60^{\circ} \mathrm{C}, 11$ days).

(a) Glass beads: $50 \mu \mathrm{m}$,

(b) Glass beads: $100 \mu \mathrm{m}$,

(c) Pit resumed inside the pit.

(a)

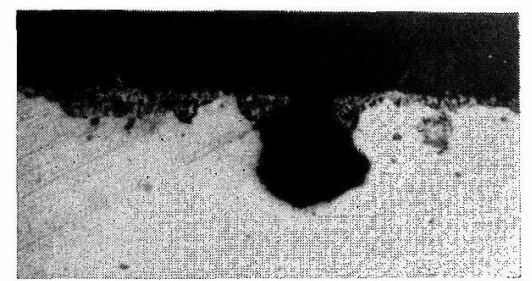

(b)

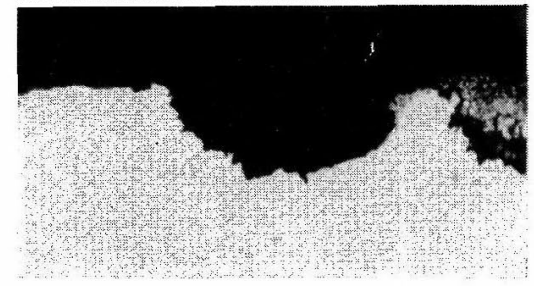

$25 \mu \mathrm{m}$

Fig. 10 Typical cross-sectional micrographs of corrosion pits after the glass beads experiment (electrolyte: $10 \mathrm{mg} / l \mathrm{NH}_{4} \mathrm{Cl}+$ $0.8 \mathrm{mg} / l$ phitic acid).

(a) Glass beads: $50 \mu \mathrm{m}$,

(b) Glass beads: $100 \mu \mathrm{m}$.

たが，電解液による差は明確でなかった。

\subsection{2 断面写真}

断面で見た孔の径はばらつきがあるるのの表面から観 察したときと同様ビーズ径 $100 \mu \mathrm{m}$ のテストピースの方 が大きいものが多く観察された。 


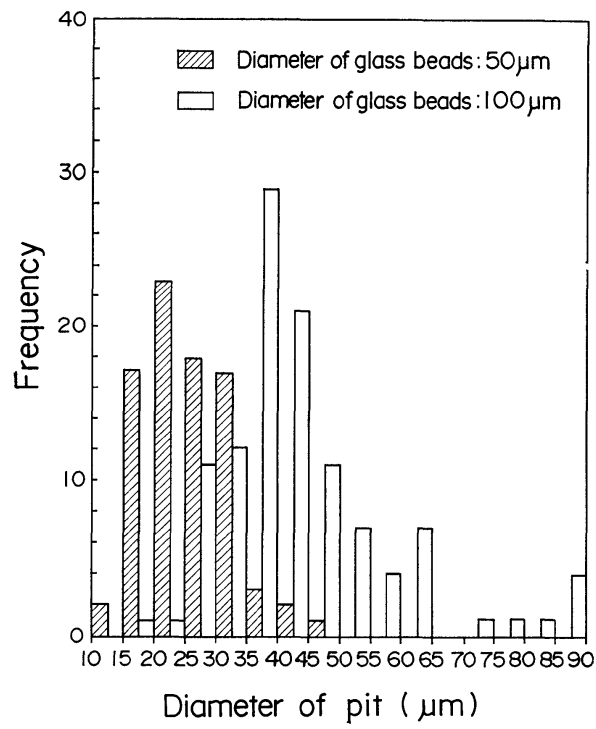

Fig. 11 Distribution of pit diameter after the glass beads experiment.

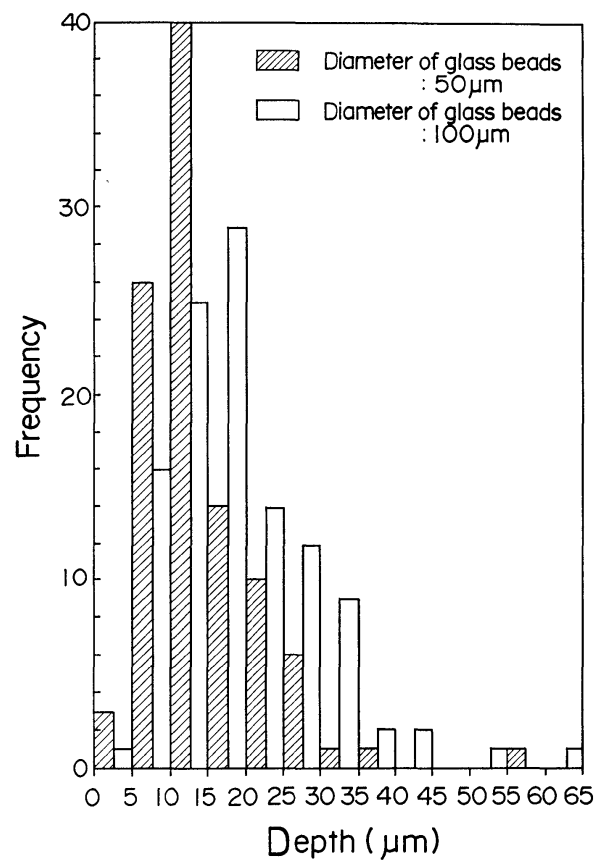

Fig. 12 Distribution of pit depth after the glass beads experiment.

Fig. 10 に示したように孔は筒状に近いゆがんだ袋状 のもの (Fig. 10 (a)), 皿状あるいは円弧状のもの (Fig. 10 (b)）が観察された。円弧状のものは筒状に発展する前段 階のものと考光られゆがんだ袋状に見光るものはその 箇所から別の方向に筒状に発展するものと推定される。

\subsection{3 孔径分布, 深さ分布}

前述のように電解液による差は明確でなく, ビーズ径
のみが孔径に影響しているように思われた。

そこで全テストピースについて，各テストピースの面 に存在する孔の径と深さを測定し，その測定值の分布を 各ビーズ径ごとに Fig. 11 と Fig. 12 亿示した。

その結果, 最頻值はビーズ径 $50 \mu \mathrm{m}$ のテストピースで は孔径 20 25 $\mu \mathrm{m}$ にありビーズ径 $100 \mu \mathrm{m}$ のテストピー スでは孔径 35 40 $\mu \mathrm{m}$ にあった。Fig. 12 に参考のため 深さ分布を示した。通電期間中の電気量はビーズ径 100 $\mu \mathrm{m}$ のテストピースが $50 \mu \mathrm{m}$ のテストピースの 2 3 倍 であったためビーズ径 $100 \mu \mathrm{m}$ のテストピースの深さが やや深くなったものと考光られる。

\section{5. 実験結果に対する考察}

前述のように等価毛管半径は表面の析出物形状・寸法 と，一般には存在する液の量によって決るる。Fig. 6 の (d)のように粒の集合に液が粒径を越えるレベルで存在 するときは, 等価毛管半径 $r_{\mathrm{e}}$ は粒の半径 $r$ のみに依存 する。液量が極端に減少し, Fig. 6 (f) の状態になると液 量の減少とともに $r_{\mathrm{e}}$ は小となり, Fig. 7 から毛管力が 大となる。

模擬実験に抒いて, 実験初期の状態は, Fig. 6(d) 飞対 応する。この条件のるとでは $r_{\mathrm{e}} / r=0.23$ であるのでビー ズ径 $50 \mu \mathrm{m}$ 及びビーズ径 $100 \mu \mathrm{m}$ に対する $r_{\mathrm{e}}$ の計算值 はそれぞれ $11.5 \mu \mathrm{m}$ 及び $23 \mu \mathrm{m}$ となる。これらの值は 最密充媜されたガラスビーズの空間に電解液が存在する ときの $r_{\mathrm{e}}$ であり, 模擬実験では最密充媜は実現されず, $r_{\mathrm{e}}$ は上記の数値より大きくなっていたと考光られる。ま た，接触角は一般に零度より大きいから毛管力は Fig. 7 より求められる上記 $r_{\mathrm{e}}$ に和忷る接触角零度の場合の毛 管力よりも小さい毛管力であり，これらが原因となっ て, 実験結果ではビーズ径 $50 \mu \mathrm{m}$ の場合孔径 $20 \sim 25$ $\mu \mathrm{m}$, ビーズ径 $100 \mu \mathrm{m}$ の場合 $35 \sim 40 \mu \mathrm{m}$ と上記 $r_{\mathrm{e}}$ 值の 約 2 倍になったものと考光られる。

また，実験結果に新いて，大きな腐食孔の中に小さな 腐食孔が観察されたのは, 腐食の進行（大きな腐食孔の 進行) とともにビーズ間の電解液の量が減少して Fig. 6 (e)を経て Fig. 6 (f) の状態となり等価毛管半径が小さく なったためと推測される。

\section{6. 結 言}

腐食現象に毛管力が影響していると思われる事例につ いて, 電解質を保持している金属表面の析出物形状と寸 法及びそこに存在する液の量によって決まる毛管力の作 用が腐食孔の径を決定している可能性を述べ，異なる径 のガラスビーズを用いた模擬実験によって毛管力の作用 を検証することを試みた。

その結果から腐食孔の孔径にビーズ径が影響している 
ことが明らかになった。この結果は, 湿潤状態で起こる 腐食が毛管力の影響を受けることの一つの例証と考古 る。

(Received April 8, 1987)

\section{文献}

1）山内重徳, 永田公二, 佐藤史郎, 下野三樹雄：伸
銅技術研究会誌, 22 (1983).

2）高田 昭, 溝口理文, 大川喜久二，山口哲夫：藤 倉電線技報, No. 55 (1976).

3）松岡宏昌, 松永義弘, 出水通之輔, 武岡康男: 第 31 回腐食防食討論会予稿集, (1984). 